\title{
Тувинские старообрядцы на страницах советской периодики
}

\author{
Елена С. Данилко \\ Институт этнологии и антропологии им. Н. Н. Миклухо-Маклая РАН, Российская Федерация
}

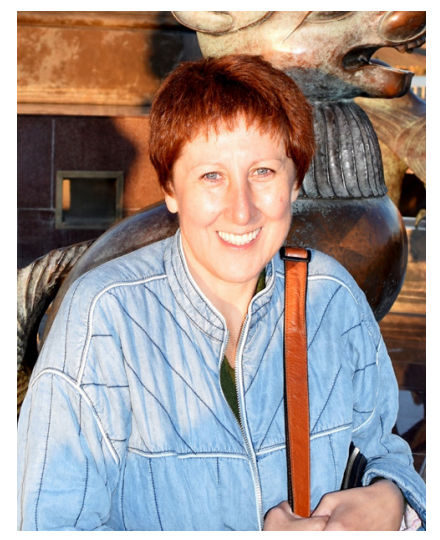

В статье проанализированы материалы, посвященные старообрядцам Тувы и опубликованные на страницах местной периодики с 1924 до конца 1980-х г2. Советские региональные газеты редко привлекаются исследователями старообрядчества в качестве материала для анализа в силу их идеологической ангажированности и необъективности фактической информации. В связи с этим в настоящей статье при обращении к газетам советской Тувы ракурс смещается с извлечения фактов об изучаемом сообществе на способы его репрезентации, что позволит обнаружить иные аналитические перспективы и избежать однозначной линейности интерпретаций.

В исследовании выявляются количественные (частота упоминаний старообрядцев в прессе в разные годы) и качественные (содержание материалов, стереотипы, идеологическая направленность, риторические приемы, визуальный контент и т. д.) параметры публикаций. Так, в статье представлен вариант внешней репрезентации одной из конфессиональных групп Тувы, её взаимодействие с окружающим населением.

Культурные особенности группы показывались в прессе сквозь идеологическую линзу. В публикациях образы старообрядцев наделялись преимущественно негативными характеристиками и фиксировали периферийное и маргинальное местоположение сообщества в социуме. Эти характеристики варьируются, - хотя и в границах жесткой атеистической рамки, - в зависимости от исторического момента. В первые годы советской власти старообрядцы предстают, прежде всего, ее политическими противниками, когда их религиозная принадлежность усиливает социально-классовую чуждость группы. Впоследствии это противостояние смещается в область идеологического соперничества, когда образ старообрядцев конструируется в оппозициях суеверного/ научного, отсталого/ передового, единоличного/ коллективного. В определенные периоды старообрядиы вовсе теряют черты религиозного сообщества, растворяясь в массе советских тружеников и оказываются представленным на страницах газет лишь как участники социалистического строительства.

Ключевые слова: старообрядчество; тувинское старообрядчество; религиозное сообщество; Тува; периодика; Тувинская правда; история Тувы; советский период; внешняя репрезентация; история СМИ

Статья подготовлена в рамках гранта, предоставленного Министерством науки и высшего образования Российской Федерации (№ соглашения о предоставлении гранта: 075-15-2020-910).

\footnotetext{
Данилко Елена Сергеевна - доктор исторических наук, главный научный сотрудник, заведующая Центром визуальной антропологии Института этнологии и антропологии РАН, профессор РАН. Адрес: 119334, Россия, г. Москва, Ленинский пр-т, д. 32А. Тел.: + 7 (495) 938-18-20. Эл. адрес: Danja9@yandex.ru
}

DANILKO, Elena Sergeevna, Doctor of History, Chief Research Fellow and Head, Visual Anthropology Center, N. N. MiklouhoMaclay Institute of Ethnology and Anthropology, Russian Academy of Sciences. Postal address: 32A Leninsky Ave., Moscow, 119334, Russia. Tel.: +7 (495) 938-18-20. E-mail: Danja9@yandex.ru ORCID ID: 0000-0002-4231-4759 


\title{
Tuvan Old Believers on the pages of the Soviet periodicals
}

\author{
Elena S. Danilko \\ N. N. Miklouho-Maclay Institute of Ethnology and Anthropology, Russian Academy of Sciences, \\ Russian Federation
}

\begin{abstract}
The article focuses on materials on Old Belief in Tuva published in the local press from 1924 to late 1980s. Due to their ideological bias and prejudiced reporting of facts, Soviet regional newspapers have rarely been used by scholars of Old Belief as sources of information. In this article we study the newspapers of Soviet Tuva with our focus shifted from the information on the community to modes of its representation. This will help us discover new analytical perspective and avoid flat and straightforward interpretation.

Our study traces both quantitative (such as the frequency of mentioning Old Believers in the media in various years) and qualitative (the materials' content, stereotypes, ideological bias, rhetorical devices, visual content, etc.) The article also presents a model of external representation of one of Tuva's confessional groups in its interaction with other population.

In the press, the cultural features of this group were presented through an ideological lens, with Old Believers shown mostly in the negative light, as a periphery and marginal community, which reflected their status in society. Depending on the agenda, this light could be varied, but variation stayed within the strictly atheistic approach. In the early years of the Soviet regime Old Believers were primarily portrayed as its political opponents, with their religious identity enhancing their status as social and class enemies. Later, the confrontation shifts into the sphere of ideological rivalry where the Old Believers are constructed through binary oppositions of science v. prejudice, progressive v. backward, collectivism v. individualism. At times, Old Believers are not even seen as a religious community: they get dissolved in the mass of Soviet working class and only appear on the pages of Soviet newspapers as participants of "Socialismbuilding"
\end{abstract}

Keywords: Old Belief; Old Belief in Tuva; religious community; Tuva; mass media; The Tuvan Pravda; history of Tuva; Soviet period; external representation; history of mass media

\section{Financing:}

The article was supported by a grant by Ministry of Science and Higher Education of Russian Federation (grant agreement No. 075-152020-910). periodicals]. New Research of Tuva, 2021, no. 3, pp. 61-74. (In Russ.). DOI: https://www.doi.org/10.25178/nit.2021.3.5

\section{Введение}

Старообрядческие общины, сформировавшиеся в Туве в ходе переселенческих процессов на рубеже XIX-XX веков и сосредоточенные территориально в восточных и северных районах (Тоджа и КааХемский кожуун), постепенно стали неотъемлемой частью местного сообщества (Татаринцева, 2006: 32). Информация о них появляется в дореволюционных периодических изданиях об Урянхайском крае и вполне закономерно обнаруживается на страницах первой тувинской газеты «Красный пахарь».

Советская региональная периодика, несмотря на обилие и разнообразие имеющихся изданий, на их сохранность и доступность в библиотечных хранилищах, редко привлекается исследователями старообрядчества в качестве источника информации и материала для анализа. Возможно, это связано с тем, что советское время в принципе пока остается наименее изученным в старообрядческой историографии, в силу целого ряда причин, порожденных самой эпохой - от периферийности религиозной проблематики в тот период до последующей закрытости архивов (Боченков, 2019: 21). Кроме того, можно предположить, что исследовательский интерес к идеологизированной прессе естественным образом снижается за счет изначального искажения содержащейся в ней фактической информации. В связи с этим, обращаясь к газетам советской Тувы, мне хотелось бы несколько сместить ракурс с извлечения фактов об изучаемом сообществе на способы его репрезентации, что позволит обнаружить иные аналитические перспективы и избежать однозначной линейности интерпретаций. 
Таким образом, в настоящей статье будут рассмотрены материалы, посвященные старообрядцам Тувы и опубликованные на страницах первой советской газеты в регионе, которая оставалась основным печатным органом республики с 1920 по 1980-е годы.

С 24 июля 1924 г. печатный орган районного бюро ВКП (б) и исполкома Русской трудовой самоуправляющейся колонии в Республике Танну-Тува начинает выходить регулярно. Он несколько раз меняет свое название, с 1931 г. «Красный пахарь» преобразуется в «Новый путь», с 1932 г. - это газета «Вперед» и, наконец, с 1942 г. по настоящее время за изданием закрепляется название «Тувинская правда». Несколько раз, в зависимости от ведомственной принадлежности и перемен на уровне государства, обновлялся и ее статус. Она была органом ЦК и Кызыльского горкома Тувинской народнореволюционной партии и Малого Хурала Тувинской Народной Республики, а с вхождением Тувы в состав СССР - сначала (с 1944 г.) областной, затем (с 1961 г.) республиканской газетой. Варьировались также формат и тираж издания, сначала по нарастающей, достигнув максимума в середине 1970-х, когда оно выходило шесть раз в неделю тиражом 25 тысяч экземпляров, однако уже в 1990-е эти показатели сократились почти в десять раз (Маадыр, Седип-оол, 2020: 91).

Конечно, эта газета была далеко не единственной в Туве. Вместе с тем, именно она в течение всего советского периода оставалась наиболее массовым печатным органом, распространяемым на всей территории республики. Отсутствие аннотированных указателей, цифровых копий и, соответственно, возможности иметь хотя бы примерное представление о содержании каждого выпуска, превращает практическую работу с газетами в трудоемкий и долговременный процесс, когда знакомство только с одной годовой подшивкой может занимать от двух до нескольких часов. Именно это обстоятельство определило необходимость выбора определенного издания, и он был сделан в пользу «Тувинской правды». Я стремилась сделать максимально репрезентативную выборку. К сожалению, некоторые лакуны образовались по объективным причинам. Так, номера, выходившие с 1932 по 1939 гг., отсутствуют в фондах Российской государственной библиотеки и оказались мне недоступны, равно как и отдельные номера в другие годы. Но издания с 1924 по 1931 гг., а также с 1940 по 1970 гг. были рассмотрены почти полностью. При изучении номеров газеты периода с 1970 по 1991 гг. делались равномерные пропуски через один-два года, как из-за увеличившегося объема (6 номеров в неделю), так и в силу однотипности и малой информативности публикуемых материалов.

Меня интересовали частота упоминаний старообрядцев в прессе в разные годы и, конечно, содержание материалов, их проблематика, идеологическая составляющая, риторические приемы, визуальный контент, словом, все то, что позволило бы представить вариант внешней репрезентации одной из конфессиональных групп Тувы и её место в системе взаимодействий с окружающим населением.

\section{«Нельзя ли батю ударить по “набату”?»}

Работа редакции первой газеты была построена на тесном взаимодействии с сельскими корреспондентами, которые добывали информацию на местах и вербовались из наиболее активных крестьян. Учитывая, что издание газеты было организовано силами русской колонии в Туве, то сначала были охвачены русские же поселки, то есть в том числе те, где проживали старообрядцы. Неслучайно один из селькоров В. Ермолаев, рассказывая о «зубастости» «Красного пахаря» и поднимаемой им бури, упоминал реакцию именно старообрядческой деревни (Танова, 1979: 13-14).

Материалы газеты являли собой большей частью донесения с мест имели краткую и выразительную, - плакатную, - форму и оставались анонимными, точнее, подписанными звучными, язвительными, часто «колкими», псевдонимами: Шило, Зацепка, Луковка и т. п. В небольших заметках, часто в несколько строк, селькоры анонсировали какие-то события, рассказывали о достижениях, разоблачали непорядочных граждан, их «героями» нередко становились и старообрядцы.

Например, материал с говорящим названием «Бог простит» и подписанный псевдонимом «Жесткий» гласил:

«Медведевка. Была сдача в налог шерсти летнины. А некоторые богобоязливые старички и старушки вместо летнины зимнинку дали. Где-же у этих граждан добросовестность?»1

${ }^{1}$ Жесткий. Бог простит // Красный пахарь. 1926, 5 января, № 1. 
Близка по содержанию и история, описанная неким Очевидцем из пос. Верховье, где очень религиозный гр. Тимофей Юрков якобы наживается на бедноте, скупая далембу по дешевой цене и сбывая ее тувинцам за белку или заставляя бедняков отрабатывать за сено. «Где же его религия?» вопрошает Очевидец, - «Надо бы кому следует познакомиться с этим гражданином!» ${ }^{1}$ Другой селькор, рассказывая о «фокусах» попа Шарыпова, якобы ведущего агитацию за снижение процентов самообслуживания, также призывает обратить на него пристальное внимание и «ударить батю по набату»².

Старообрядцы, с их показной, по мнению селькоров, религиозностью, неизменно оказываются на острие их пера. Именно они составляют социально чуждый молодой советской власти класс, с которым ей предстоит бороться. Это хитрые кулаки, наживающиеся на бедноте, такие как мельник Потылицын, о котором пишет корреспондент «Ухо» ${ }^{3}$ или кузнец Вяткин из поселка Мокеевка, закрывший свою кузницу для бедноты и т. д. ${ }^{4}$

Развернув кампанию по привлечению крестьянина середняка во вновь созданные структуры, редакция использует метафору выбора двух путей, к слову, популярную у современных старообрядцев (Быкова, Костров, 2019: 6). Один, вместе с бедняком и рабочим, ведет середняка к благоденствию и просвещению, второй, с кулаком-мироедом, - к разорению и невежеству (рис. 1).

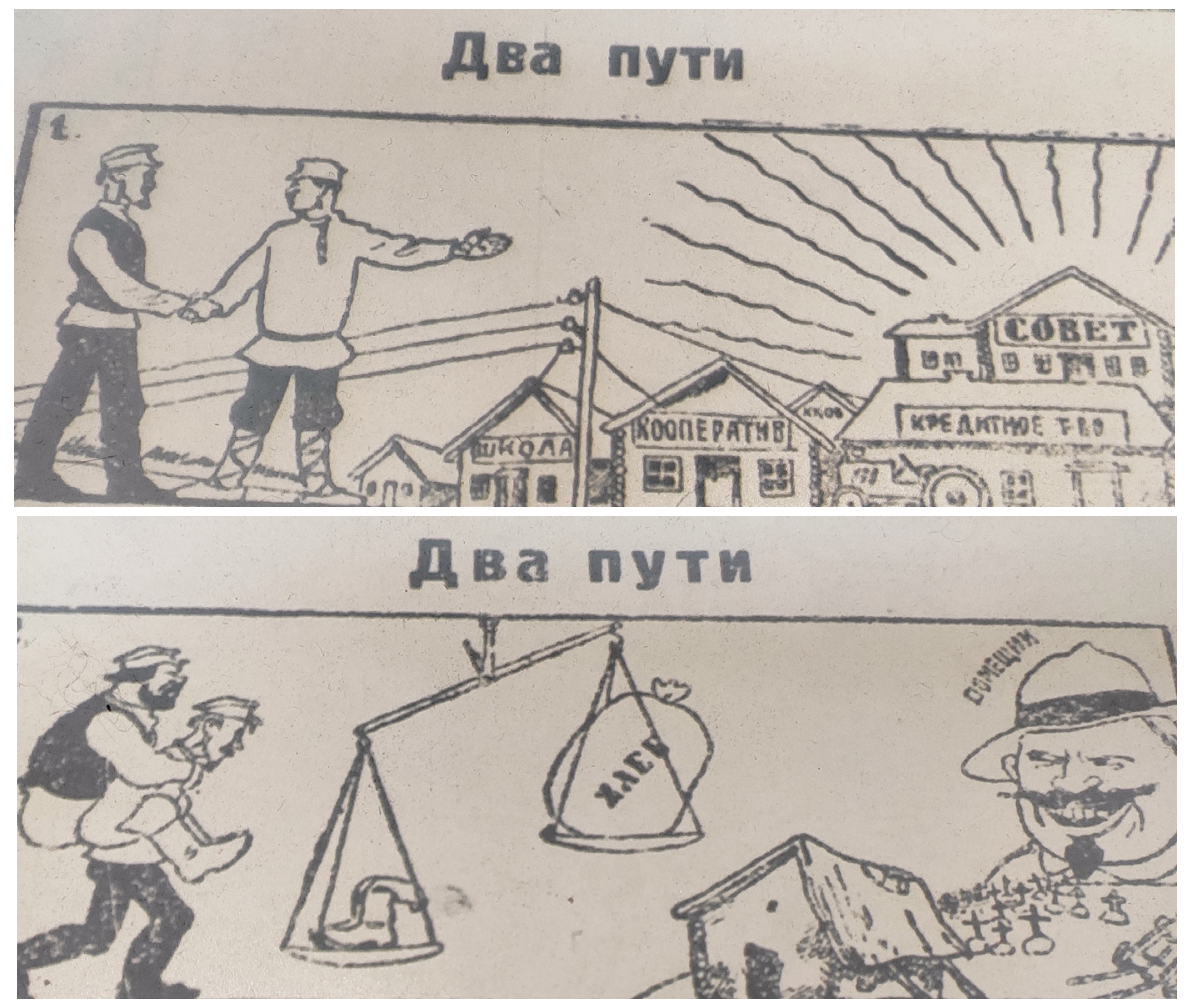

Рис. 1. Коллаж иллюстраций «Два пути крестьянина-середняка» из газеты «Красный пахарь» 1924 г., 23 марта, № 11.

Fig. 1. "Two Paths for a Serednyak Peasant": a collage from the Krasny Pakhar' (Red Plowman) newspaper, 1924, No.11, March 23.

Подобная риторика противопоставления религиозного мракобесия и просвещения звучит и в материалах о лицемерии старообрядцев, которые, прикрываясь разговорами о грехе, нарушают правила общественной морали и препятствуют развитию молодежи. Например, как пишет селькор «Негодный»,

\footnotetext{
${ }^{1}$ Очевидец. Эксплуататор и спекулянт // Красный пахарь. 1928, 6 сентября, № 16.

${ }^{2}$ Берестов Игнатий. Фокусы попа Шарыпова // Новый путь. 1931, 10 февраля, № 15.

${ }^{3}$ Наши селькоры говорят, что... // Красный пахарь. 1926, 5 января, № 1.

${ }^{4}$ Бедняки. Ищут где лучше // Красный пахарь. 1929, 26 декабря, № 39.
} 
«В Максимовке православное население разделяется на религиозные секты. Секты стараются иметь мало сношения друг с другом. Не так давно все секты загуляли, наматерились вдоволь и чуть не передрались. Это они не считают за грех. А вот детей не спектакли не пускают - грех, говорят, там умным развлечениям учат. А разве плохо будет, максимовцы, если наши дети действительно будут умными сознательными крестьянами» ${ }^{1}$.

«Стыдно, Мальцев, так делать» называет другой корреспондент Зацепка свою заметку, в которой говорится, что в поселке Успенка старовер Мальцев призывал родителей не пускать детей на конференцию, где их могут записать в пионеры². А селькор Деревенский приводит пример из поселка Ильинский, как верующие родители, не желающие, чтобы их дети «получали просвещение», не пустили в школу Луку Сасина. Пришлось Луке вернуть обратно полученные учебники³.

В этом же поселке Ильинский, пишет селькор Проезжий, в 1929 г. открылась «староверская школа, в которой учат детей по старинной азбуке: аз, буки, веди, глагол и так далее». Учитель Бортников Николай за «одурманивание детей» имеет приличный заработок - по 12 рублей с ученика 5 .

Таких корреспонденций на страницах «Красного пахаря» обнаруживается множество. Информация в них из разных мест, но и содержание ее, и смысловой посыл, не отличаются разнообразием. Это либо косность и невежество одурманенных религией людей, либо их аморальное, противоречащее религиозным нормам, поведение. Доказательства невежества верующих, как правило, основываются на отказе взаимодействовать с советскими организациями, включая медицинские учреждения. Например, к врачу или ветфельдшеру призывает впредь обращаться селькор Проезжий темную жену Трофима Чернова из поселка Зубаревка, которая «пригласила тувинца “пошаманить” над коровой, чтобы она подпускала теленка и отпускала молоко, заплатив за это тувинцу 1 рубль» ${ }^{6}$ Кстати, интересный момент, обнаруживающий бытовые контакты русских с местным населением. Селькоры также сообщают, что в поселках Знаменке и Федоровке наживаются на людских болезнях знахарки и шарлатаны-лекари ${ }^{7}$, в в селе Краснояровке некий Кирилл Алексеевич Чистобаев крестит верующих в мороз на улице, да еще в лошадиной колоде ${ }^{8}$.

Страшными бичами советской послереволюционной деревни предстают, судя по газетным материалам, пьянство и хулиганство. Страницы печати пестрят рассказами о хулиганских выходках разных персонажей, в том числе, обличенных властью, и призывами к трезвости. Серьезный вклад в картину морального разложения вносят, по мнению сотрудников редакции, и религиозные организации с их разгульными праздниками, пьяными Масляницами и Пасхами. Конечно, не обходится и без старообрядцев. Приведу пару примеров, подписанных характерным псевдонимом Саваоф:

«В наш поселок приехали два дармоеда попы Иван да Евсей Шарыповы. Мало-мало помолились, да и пошли по поселку собирать стакашки самогона. Насобирали порядочно. Дошли до самого богомольного старовера Какорина. Уселись пить пиво. На грех пришел коммунист Кузька и завел разговор про бога, попы спорили, спорили. Предали коммуниста анафеме, схватили шапку в охапку и тягу задали. Граждане качают головами. Вот так попы»";

«Наступил престольный праздник Введение и вот приехали в Федоровку два попа и вся их свита человек 10. Загуляли староверы с отцами духовными. Пиво рекой льется, а на этот грех, вздумали пастухи собирать свой заработный хлеб. Куда ни зайдут, везде готовятся к встрече попов. Пастухи хоть свое трудовое собирают, а попы не сеют ни пашут, а собирают житницу. Эх! Мужички, мужички. Бороды-то у вас густые, а головы - пустые» ${ }^{10}$.

\footnotetext{
${ }^{1}$ Негодный. Максимовцам пора одуматься // Красный пахарь. 1926, 21 января, № 3.

${ }^{2}$ Зацепка. Стыдно, Мальцев, так делать // Красный пахарь. 1926, 21 января, № 3.

${ }^{3}$ Деревенский. Селькоры говорят // Красный пахарь. 1926, 30 января, № 5.

${ }^{4}$ Негодный. Максимовцам пора одуматься // Красный пахарь. 1926, 21 января, № 3.

${ }^{5}$ Проезжий. Староверская школа // Красный пахарь. 1929, 8 февраля, № 5.

${ }^{6}$ Проезжий. К врачу, а не к шаману // Новый путь. 1931, 7 апреля, № 26.

${ }^{7}$ Селькор. Шарлатана нужно одернуть // Красный пахарь. 1926, 5 января, № 2; Иванов. Знахарка // Красный пахарь. 1930, 18 июня, № 16.

${ }^{8}$ Кружок селькоров. Крещение в лошадиной колоде // Красный пахарь. 1927, 1 января, № 1.

${ }^{9}$ Шар. Начальство загуляло // Красный пахарь. 1926, 6 февраля, № 5; Саваоф. И отцы духовые не брезгуют // Там же.

${ }^{10}$ Ни сеют, ни жнут, а даром берут // Красный пахарь. 1926, 5 января, № 1.
} 
Приведенные приемы дискредитации идеологического противника стандартны, в их использовании на страницах советских газет нет ничего необычного, пропаганда не нуждается в полутонах, взаимные обвинения, как правило, всегда сопровождаются навешиванием ярлыков и представлением фактов в выгодном для одной из сторон свете. Здесь интересно другое - само наличие такого количества материалов, так или иначе связанных со старообрядцами, говорит о них как об активных акторах развернувшегося исторического процесса. Отсутствие их голосов на страницах печати совсем не свидетельство их молчания за пределами официального публичного дискурса. Показателем чего служит даже используемая их оппонентами лексика и сама логика построения сообений, нередко апеллирующих к воображаемым и возражающим собеседникам - «ревнителям древнего благочестия», «рабам божьим», «святым старичкам».

Присутствуют в текстах газетных агитаторов и традиционные для старообрядцев эсхатологические категории, с которыми те связывают все новшества - колхозы, коллективные и индивидуальные займы, пионерию и комсомол. Отгораживаясь от «коллективов - антихристов», отказываясь от общения с «кадровыми» и «обмирщения» старообрядцы воссоздают привычные стратегии самосохранения, модели ухода или замыкания в границах своего сообщества ${ }^{1}$.

«У нас в поселке Мокеевке живут староверы, - пишут селькоры. - Детей они в школу не отдают. При рождении ребят не регистрируют. В кооперацию не вступают. Все эти организации, видите ли, бесовского происхождения, смертный грех в них вступать. Они греха на душу не возьмут и решают уехать от “антихристов” в Монголию, на речку Изрын»².

Другой рассказ о старообрядческом «спасении души» представлен неким корреспондентом Мокшиным, который описывает глухую тайгу, места, куда «ни только на телеге, а даже верхом трудно пробираться». Здесь живут отшельники-староверы, осторожные и скрывающие правду даже о добытом звере, не отдающие детей в школы, но грамотные и со своими обычаями․․

С одной стороны, эти тексты воспроизводят стереотипные образы старообрядцев, с другой - доносят информацию о неизбежных, проникающих в их быт переменах, которые они концептуализируют привычным для себя способом. Кроме того, влияние подобного образа старообрядцев оказывает и субконфессиональная особенность группы: присущее всем старообрядческим направлениям стремление укрыться от мира наиболее последовательно проявляется именно у часовенных, и именно советское время актуализирует его в полной мере (Покровский, Зольникова, 2002: 35). Не последнюю роль играет и территориально-географический фактор - некоторая периферийность региона, что позволяет в большей мере поддерживать социально-культурную дистанцию (Стороженко, 2019: 10).

Набирающие темпы коллективизация и раскулачивание, борьба за грамотность и судебные процессы, - остаться в стороне от этих событий становится все сложнее, и старообрядческие семьи вовлекаются в них наравне с другими жителями республики. Их фамилии - все чаще в заметках о приговорах над кулаками, в материалах о последствиях гражданской войны, где они предстают «бывшими контрреволюционерами», «старыми бандитами» как братья Потылицыны из поселка Грязнуха или Захаровы из Федоровки ${ }^{4}$.

Приведу красноречивый пример из газеты за 1931 г., где селькор Без № рассказывает о некой Саломее Питиримовой из поселка Туран. Она пытается «агитнуть на собрании, что план посева непосилен» и заявляет колхозникам: «Я не машина, чтобы работать, я детей рожу и пашню пашу, изнашиваюсь».

«А кто же она такая? - задается вопросом «безномерный» корреспондент. - Муж Питиримовой расстрелян, как участник шмаковской банды; деверь - Андрей Питиримов расстрелян за участие в банде 1930 года, один из племянников выселен за это же из-за пределов Тувы. Два брата - Афанасьевы - кулаки, злостно сокращают посев» ${ }^{5}$.

Однако далеко не всегда старообрядческие фамилии обнаруживаются лишь среди противников и «злостных врагов» нового строя. Революция и гражданская война и последовавшая за ними грандиозная ломка деревенского жизненного уклада сместили традиционные ориентиры, раздробили семьи и родовые кланы, разместив их по разные стороны социальных границ. Одни стремятся остаться

\footnotetext{
${ }^{1}$ Ганзбург. Где слово «коллектив» - это антихрист // Красный пахарь. 1930, 26 марта, № 8.

${ }^{2}$ Бедняки. Ищут, где лучше // Красный пахарь. 1929, 26 декабря, № 39.

${ }^{3}$ Мокшин. Староверы спасают душу // Красный пахарь. 1928, 14 августа, № 13.

${ }^{4}$ Укусил. Подняли голову // Красный пахарь. 1930, 27 мая, № 14

${ }^{5}$ Без №. Яблочко от яблоньки - не далеко // Новый путь. 1931, 22 мая, № 38.
} 
в стороне от деревенской жизни, как Автоном Стародумов, поселившийся выше пос. Бельбей, другие уходят в колхоз, но не получают доли от родительского хозяйства, как братья Гурковы из поселка Бояровка ${ }^{1}$.

Старообрядцы вынуждены приспосабливаться к происходящим переменам, не только вступать в колхозы, но и занимать административные должности. Так, героем двух публикаций в газете становится, возможно, основатель упомянутой выше староверческой школы Николай Бортников. В первой селькор обличает его как кулака и сектанта, обманом проникшего в местный совет, а во второй - дается опровержение, где Бортников предстает хорошим хозяйственником, за которым идет вся беднота (57 голосов против двух $)^{2}$.

Целая серия заметок посвящена некоему Ивану Килину, также занимавшему пост в местном совете, но скомпрометировавшему себя недостойным поведением ${ }^{3}$. О том, что перемены происходили медленно и давались нелегко, можно судить по многим материалам. Все еще на некотором перепутье находится «богобоязненный председатель» Бояровского совета. «Дома богу не молится, а как пойдет по домам крестьян, с делами, так и начинает кресты отвешивать. Как будто бы председателю это к лицу», - пишет о нем Самовидец ${ }^{4}$. Под дудку кулаков пляшет и бывший красный партизан Ф. Шарыпов из той же Бояровки, отговаривающий своих товарищей вступать в колхоз 5 . А душевные метания комсомольца Карпушки Стародумцева завершаются в итоге решением «спасать душу» в лесу у старца Иосифа ${ }^{6}$.

Вообще душевные метания, дружеские отношения и личная жизнь теряют приватность, дела семейные отныне должны вестись с учетом классовой линии. Показательна попавшая в печать история демобилизованного красноармейца, кандидата ВКП(б) Николая Фунтикова, «день и ночь страдающего по бандитской дочери Наталье Ивановой», забывшего про партийные собрания и политкружок. В итоге, женившийся на кулацкой дочери Фунтиков был исключен из туранской ячейки партии, как потерявший классовое чутье

Таким образом, материалы первой тувинской газеты 1920-х годов содержат довольно много разнообразной информации о старообрядцах. Хотя очевидные пропагандистские задачи, стоявшие пред редакцией, полностью определяют ее содержание и формы презентации сообщества, представители которого маркируются как чуждые для новой жизни социальные элементы. А их религиозная принадлежность лишь подкрепляет эту инаковость. Вместе с тем, доминирующий идеологический контекст неоднороден, сквозь имеющиеся в нем зазоры проступают заглушенные голоса самих старообрядцев, их интерпретации реальности и реакции на нее, формирующие традиционный спектр адаптаций - от ухода до встраивания в динамичную социальную ткань.

\section{«На далекой таежной реке...»}

Газетные материалы 1930-х годов, как уже было сказано, оказались для меня, за исключением первых двух лет, недоступны. Но судя по статье начала 1941 г. и несмотря на жесткую атеистическую кампанию, в воспитательной массовой работе случались провалы. Так, например, в пос. Чкаловском, «так называемые старики» решили окрестить «по старым обычаям» новорожденного младенца в семье Железкиных. Ситуация преподносится автором статьи в ироничном ключе, как что-то нелепое, смешное и одновременно уродливое: обряд совершает в бочке то ли из-под огурцов, то ли из-под капусты, какаято случайная старушка, которой «нечего терять на этом свете». На ее сокрушения по поводу отсутствия у нее священного сана зачинщики лишь машут рукой: «Где его найдешь сейчас, тот сан?» Бабка вместо молитв шепчет какую-то ерунду, не таинство - а «самодеятельность», которая оставляет у молодых

\footnotetext{
${ }^{1}$ Хаеркан. Лодыри // Красный пахарь 1929, 6 марта, № 7.

${ }^{2}$ Шульц. Опровержение на заметку «Ни одного сектанта и кулака в Совет» в № 6 «Красного пахаря» // Красный пахарь 1929, 6 марта, № 7.

${ }^{3}$ №. Килина надо сменить // Красный пахарь. 1926, 26 февраля, № 12; Очевидец. Килина по шее и в Нарсуд // Красный пахарь. 1926, 6 февраля, № 5; Луковка. Нам таких в райсовет не нужно // Красный пахарь. 1926, 6 марта, № 9; Антипин И. К суду ретивых борцов // Новый путь. 1931, 10 февраля, № 15.

${ }^{4}$ Самовидец. Богобоязненный председатель // Красный пахарь. 1926, 6 марта, № 9.

${ }^{5}$ Г. Играет под дудку кулаков // Красный пахарь. 1929, 14 марта, № 7.

${ }^{6}$ Странички быта // Красный пахарь. 1926, 12 марта, № 10.

${ }^{7}$ Оса. Пляшет под бандитскую дудку // Красный пахарь. 1930, 3 декабря, № 35; Кулацким дружкам не место в партии // Красный пахарь. 1930, 10 декабря, № 36.
} 
лишь чувство стыда за исковерканную радость появления на свет советского гражданина. «Так мертвое цепляется за живое», - заключает автор, хотя стоит лишь усилить воспитательную работу, и оно исчезнет полностью. И действительно старообрядцы, как религиозное сообщество, постепенно исчезают с газетных страниц в последующие годы.

В целом, информационная повестка военных лет и до середины 1950-х годов определяется совершенно другим историческим контекстом, когда задачи антирелигиозной пропаганды отодвигаются на второй план. Даже в центральных изданиях того периода почти отсутствуют статьи атеистического содержания (Смолкин, 2021: 159). Кроме того, главной мишенью в борьбе с религией оставалась именно официальная православная церковь, а конфессиональное многообразие страны учитывалось им лишь в некоторой степени. Возможно, поэтому старообрядцев почти не коснулась так называемая сталинская религиозная оттепель (Филатов, 1997: 80). По крайней мере, информации об официально зарегистрированных старообрядческих общинах в номерах теперь уже «Тувинской правды» за этот период не появилось.

Сама «Тувинская правда» выглядела иначе, чем предшествовавшие ей «Красный пахарь», «Новый путь» И «Вперед»: ее объем значительно вырос, на смену коротким плакатным заметкам, подписанным звучными псевдонимами, пришли материалы, оформленные в виде более развернутых авторских статей. В структуре газетных материалов в течение всего советского периода выделялись три тематические части, в первой обычно представлялась ситуация в стране, две другие включали обзор мировых событий и местную хронику, которая в некоторых номерах сводилась к минимуму. Таким образом региональные новости, включенные в широкий социально-исторический контекст страны и мира, несколько теряли значимость, но обретали верный идеологический вектор.

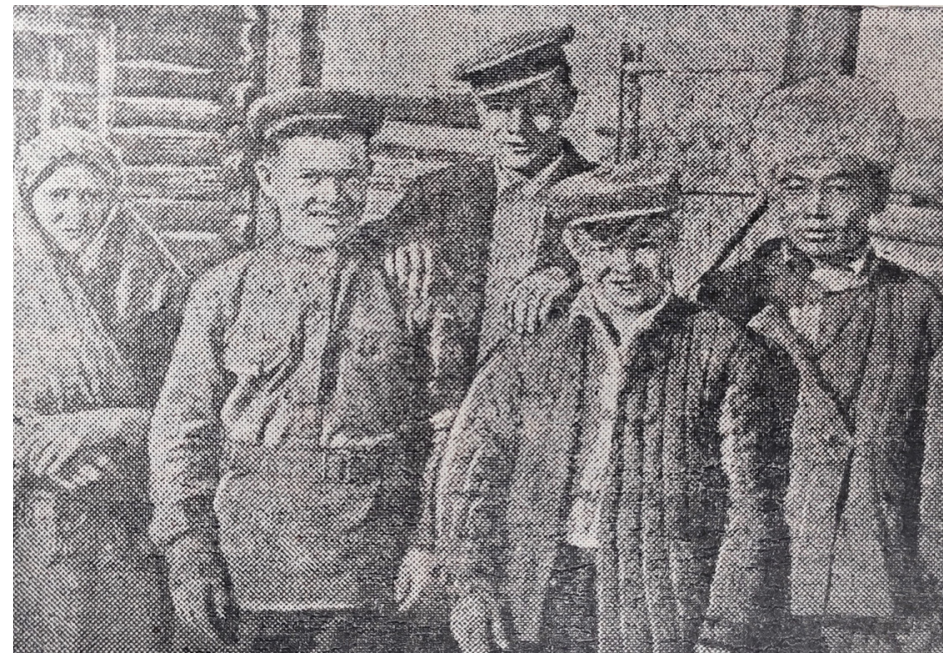

Рис. 2. Колхоз «Свобода труда» Улуг-Хемского района. Звеньевые Лайзап, Фитин, Блинов, Горошников и Зырянова. Иллюстрация из газеты «Тувинская правда» 1947 г., 30 мая, № 63.

Fig. 2. Team leaders (zven'yevoi) Laizap, Fitin, Blinov, Goroshnikov, Zyryanova, "Svoboda Truda" (Freedom of Labour) kolkhoz, Ulug-Khem rayon. From Tuvinskaya Pravda, 1947, No.63, May 30.

Жители старообрядческих поселков, конечно, присутствуют в публичном пространстве послевоенной Тувы, но теперь это обычные советские граждане, колхозники, сплавщики леса, работники животноводческих ферм и промысловых артелей. Они образцовые труженики и передовики сельскохозяйственного производства. Об их возможной связи со старообрядчеством можно судить лишь по звучащим несколько архаично именам, Хрисантий, Илларион, Саломея, Домна, - и уже знакомым нам из ранних публикаций фамилиям - Килины, Потылицыны, Юрковы, Буторовкины, Стариковы, Березиковы. Эти фамилии принадлежат героям публикаций и встречаются в подписях под статьями о колхозных достижениях ${ }^{1}$ (рuc. 2).

Иногда мы не столько узнаем о присутствии старообрядцев из текста статей, сколько догадываемся об этом по некоторым характерным приметам, описывающим контекст, в котором оказываются персонажи. Например, в статье о трудовой биографии деревенской фельдшерицы Елизаветы Поповой из Каа-Хемского района республики присутствует пара эпизодов, демонстрирующих ее борьбу с деревенскими предрассудками и косностью. В одном из них, добравшись к смертельно больной женщине сквозь дремучую тайгу, она встречает недружелюбный прием. «Мы вас не звали, один бог знает, как Варвару лечить», - прямо заявляет ей какой-то бородатый

\footnotetext{
${ }^{1}$ Ангарский В. В Тодже // Тувинская правда. 1950, 26 января, № 17; Попов П. В Каа-Хемском районе // Тувинская правда. 1950, 15 июля, № 141; Николаев Б. На ферме // Тувинская правда. 1950, 1 февраля, № 22; Гильманова Л. Закройщица Клавдия Потылицына // Тувинская правда. 1950, 6 февраля, № 27; Фатеев С. На колхозной ферме // Тувинская правда. 1950, 29 июля, № 148; Костин К. Трудовые будни // Тувинская правда. 1950, 30 июля, № 149 и др.
} 
родственник. В другой раз в подобных обстоятельствах она также слышит высказывание о боге и принятии данной им доли. Лишь ценой огромных усилий врачу удается оказать больным помощь. В рассказе присутствует несколько деталей, служащих свое рода маркерами старообрядческой среды: поселение в глухой тайге на берегу Енисея, отказ принимать лекарства со ссылкой на божий промысел, наконец, борода у несговорчивого родственника. Проводя идею о победе просвещения, автор наделяет ее противников уже знакомыми чертами людей, чей разум затемнен религией. Но в итоге они вынуждены признать преимущества рационального знания ${ }^{1}$.

Эти условные приметы - окладистая борода у мужчин, или особенным образом повязанный женский платок - иногда выделяют старообрядцев среди других советских тружеников, изображенных в газетных фото. Замечу, что визуальный контент «Тувинской правды» вплоть до 1960-х годов не отличался разнообразием, большую его часть составляли фотографии, перепечатанные из центральных изданий, прежде всего, портреты вождей, и снимки с изображением разных событий из жизни советских республик. Среди последних встречаем, кстати, фото звеньевой картофелевода Прасковьи Петровой из Бурят-Монгольской АССР, в традиционном костюме семейских старообрядцев ${ }^{2}$ (рис. 3).

Атеистические материалы начала 1950-х представляют собой обширные статьи о религии как антитезе научного мировоззрения или разоблачающие «реакционную сущность» тех или иных ее направлений - ислама, шаманизма и ламаизма, баптизма. Это статьи общего характера, каких-то сведений или примеров, имеющих отношение к региону, в них не

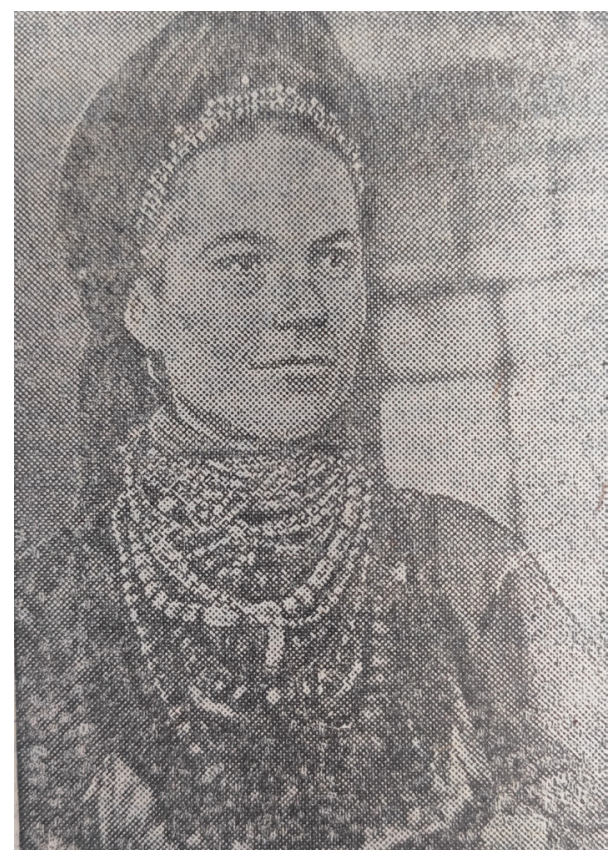

Рис. 3. Звеньевая картофелеводов Прасковья Петрова. Бурят-Монгольская АССР. Фотография из газеты Тувинская правда. 1947, 2 октября, № 102.

Fig. 3. Praskovia Petrova, team leader of potato farmers. Buryat-Mongol ASSR. From Tuvinskaya Pravda, 1947 No. 102, October 2. представлено. Старообрядчество же в этом ряду отсутствует совсем. Даже о трагических событиях марта 1951 года, когда были разорены знаменитые Дубчесские скиты (Покровский, 1991, 1992), в центральном печатном органе республике не находится ни строчки. Очевидно, сам факт существования тайных монастырей настолько противоречит официальной линии атеистического государства,

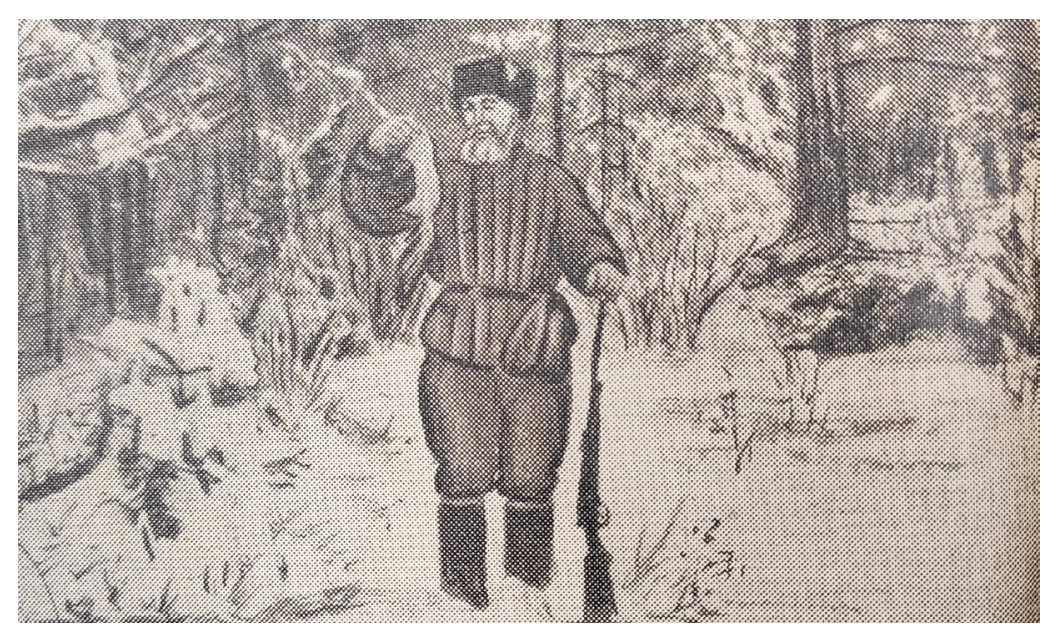

Рис. 4. Охотник Иван Балчугов. Фотография из газеты «Тувинская правда» 1956 2., 4 марma, № 48.

Fig. 4. Ivan Balchugov, a hunter. Photo from the Tuvinskaya Pravda, 1956, No 48, March 4. что даже победоносная операция по их уничтожению не выносится в публичное пространство. Старообрядцы как будто бы навсегда остались в прошлом, утратили связь с современностью, превратились в историю (рис. 4).

Поэтому неслучайно, что первые публикации, знаменующие начало новой атеистической кампании и снова включающих старообрядцев в общественный дискурс, рассказывают о событиях давно минувших дней - о гражданской войне и затаившихся в тайге скитах, укрывающих белых офицеров, переквалифицировавшихся в монахи или дюжих и хитрых кулаках, прячущих хлеб. С этих очерков 1956-1957-х го-

\footnotetext{
${ }^{1}$ Попов П. Начало большого пути // Тувинская правда. 1955, 19 января, № 13.
}

${ }^{2}$ Бурят-Монгольская АССР // Тувинская правда. 1947, 2 октября, № 102. 
дов, написанных в художественной форме, но апеллирующих к исторической достоверности, начинается новое возвращение старообрядцев на страницы местной прессы (рuс. 5).

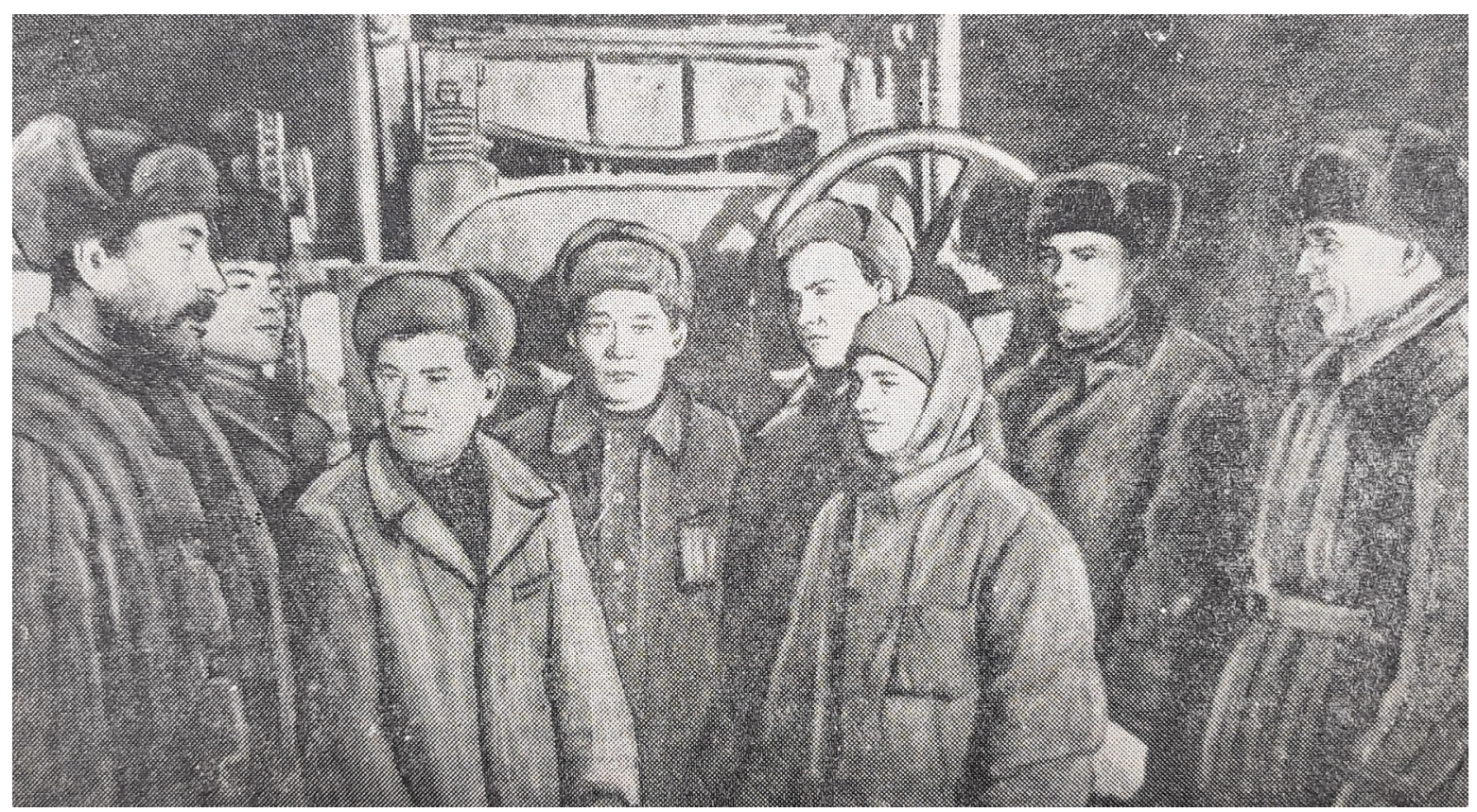

Рис. 5. Бригада М. Я. Потылицына Кызыльского лесхоза.

Фото Г. Сиротина из газеты «Тувинская правда» 1955 г., 14 февраля, № 32.

Fig. 5. M.Ya. Potylitsin's team at Kyzyl Forestry, photo by G. Sirotin,

Tuvinskaya Pravda, 1955, No. 32, February 14.

\section{«В религиозной паутине»}

Исследователи выделяют две волны масштабной атеистической кампании, развернувшейся в Советском Союзе в хрущевскую эпоху, начало первой пришлось на 1954 г., второй - на 1958 г. Если прежде религия рассматривалась как политический противник, которого следовало лишить способности к сопротивлению, то теперь на передний план идеологической борьбы выдвигалась задача построения коммунистического общества на основе научного мировоззрения, которому религия, соот ветственно, противостоит (Смолкин, 2021: 145). Средствам массовой информации в кампании отводилась одна из главных ролей. Хотя тувинская пресса, если судить по газете «Тувинская правда», включилась в нее с некоторым запозданием и заметная активность в этом направлении наблюдается только после середины 1950-х. Старообрядцам поначалу не уделялось много внимания, основной мишенью стали баптисты, считавшиеся членами «зарубежных сект». После серии обобщающих материалов о баптизме появилась статья «Дела духовные», включающая конкретный региональный материал, обсуждение которой растянулось на несколько последующих номеров ${ }^{1}$.

После этого, в январе 1960 г., подобный прием был применен и в отношении старообрядчества. Программной стала публикация агитатора И. Онищенко «В религиозной паутине», которая вышла в двух номерах газеты. Ее название говорило за себя и подкреплялось визуально изображением этой самой паутины, как бы составляющим буквицу как в старопечатных текстах 2 .

Автор предварял рассказ обширным вступлением об истории старообрядчества в целом, затем рассказывал о проявлениях его реакционной сущности в первые годы советской власти, постепенно переходя к местному материалу, изобилующему множеством устрашающих примеров. Чего стоит воскрешающий мотив кровавого навета эпический сюжет о том, как главарь бело бандитов в поселке

\footnotetext{
${ }^{1}$ Петров А. Дела духовные // Тувинская правда. 1959, 13-14 июня, № 111-112; Читатели о «Делах духовных» // Тувинская правда. 1959, 15 июня, № 115 и др.

${ }^{2}$ Онищенко И. В религиозной паутине // Тувинская правда. 1960, 30 января, № 1; 31 января, № 2.
} 
Эглет старообрядец Антон Кузнецов сначала выстрелил в директора госхоза Городищева, а затем, подставив ладони под рану, набрал в них крови врага и торжественно выпил. Или пассажи об уморенных голодом, утопленных и задушенных религиозными фанатиками детях. Приводя информацию по старообрядческим монастырям, подкрепленную для убедительности статистикой, - на 1928 г. там насчитывалось до 25 монашек, - Онищенко заключает ее пафосным заявлением о том, как зажиточные староверы развращали и безжалостно эксплуатировали юных монашек, дочерей бедняков.

Отдельные разделы статьи посвящались пользовавшимся авторитетом среди тувинских часовенных личностям - старцам Палладию и Кастору, матушке Мастрадее и другим, являющих в этих описаниях образы аморальных, жадных и лицемерных служителей культа. Для описания «фактов» из их жизни автором используется приемы художественной прозы, передающие несложные «мысли» персонажа. «Это ничего, что мы ведем неправильный образ жизни, - рассуждает "ревнитель благочестия” Палладий, - христиане этого не знают» 1 . Рассказ агитатора-атеиста, занявший несколько полос в двух номерах газеты, доводит описание злодеяний староверов до современности. Из него читатели узнают, что осколки тех скитов до сих пор сохраняются в енисейской тайге, и религиозные фанатики, живущие совсем рядом с ними, в советских поселках, как затаившиеся по глухим углам пауки затягивают к себе молодежь. При этом, в статье появляется информация о событиях военных лет, не представленная в газетах того времени, но, что снова кажется странным, не упоминается разорение скитов в 1951 г.

За статьей последовала серия читательских отзывов, полученных редакцией из разных уголков республики, каждый из которых транслировал один из аргументов атеистической пропаганды страхи за будущее детей, которых одурманивают родители, научные знания, отвергающие нелепые предрассудки, торжество советского закона и т. д. Их авторы, как правило, подкрепляли свои рассуждения примерами из личной жизни, все они когда-то столкнулись со старообрядцами, - в браке или в рабочем коллективе, и будучи поражены живучестью религиозных предрассудков и негативными человеческими качествами жадных до наживы старообрядцев, разрывали с ними всяческие отношения ${ }^{2}$.

Серию публикаций о тувинском старообрядчестве продолжили три обширных очерка, также растянутых по нескольким номерам и вышедших с зимы по осень 1962 г. Их авторы - известные в Туве люди: уже знакомый нам лектор-пропагандист И. Онищенко ${ }^{3}$, секретарь Каа-Хемского райкома КПСС Ф. Благинин ${ }^{4}$, журналист Т. Сермавкин ${ }^{5}$. Публикуется в газете и популярный писатель А. Емельянов 6 .

Тексты позволяют представить существовавший репертуар деятельности атеистического аппарата на местах. Как отмечает Виктория Смолкин, идеологию внедряет особая социальная среда, не государство («сверху») или народ («снизу»), а «середина» - функционеры, претворяющие политическую задачу в идеологическую теорию, а идеологическую теорию - в социальную практику (Смолкин, 2021: 21). Описанная практика включала лекции в сельских клубах, поездки в поселки и беседы особенно с лидерами, с верующими, информация о которых тщательно собиралась и фиксировалась. Последних старались не столько разубедить, сколько дискредитировать в глазах населения. Тон бесед варьировался от задушевно-сочувственных до наступательно-обвинительных, осуждая образ жизни верующих, авторы стремятся помочь им выбраться из «религиозной паутины». Снова используется уже знакомая метафора выбора двух путей, узкой извилистой тропинки веры и широкой светлой дороги, по которой шагают все советские люди. Многие из газетных очерков о старообрядцах позднее вошли в сборник о разных религиях Тувы ${ }^{7}$.

Материалы очерков обнаруживают удивительную живучесть религии, несмотря на многие годы существования советской власти и достижения науки. Из них мы узнаем о старообрядческих поселках, куда не проведено электричество, нет радио и телевидения, а приехавший в поселок Шивей секретарь райкома останавливается в избе у монашек. Недовольные его присутствием они все же собираются на

\footnotetext{
${ }^{1}$ Онищенко И. В религиозной паутине // Тувинская правда. 1960, 31 января, № 2.

${ }^{2}$ Обсуждаем статью «В религиозной паутине» // Тувинская правда. 1960. 6 марта, № 47; 12 марта, № $51 ; 30$ марта, № 64.

${ }^{3}$ Онищенко И. Деяния куранского наставника // Тувинская правда. 1962, 17 февраля, № 41.

${ }^{4}$ Благинин Ф. Человек из мглы // Тувинская правда. 1962, 23 сентября, № 226.

${ }^{5}$ Семравкин Т. Трагедия в домике на берегу // Тувинская правда. 1962, 2 сентября, № 208.

${ }^{6}$ Емельянов А. Вкус жизни // Тувинская правда. 1970, 3 июля, № 154.

${ }^{7}$ Правда о церковниках Тувы. Кызыл: Тувинское книжное издательство, 1961.
} 


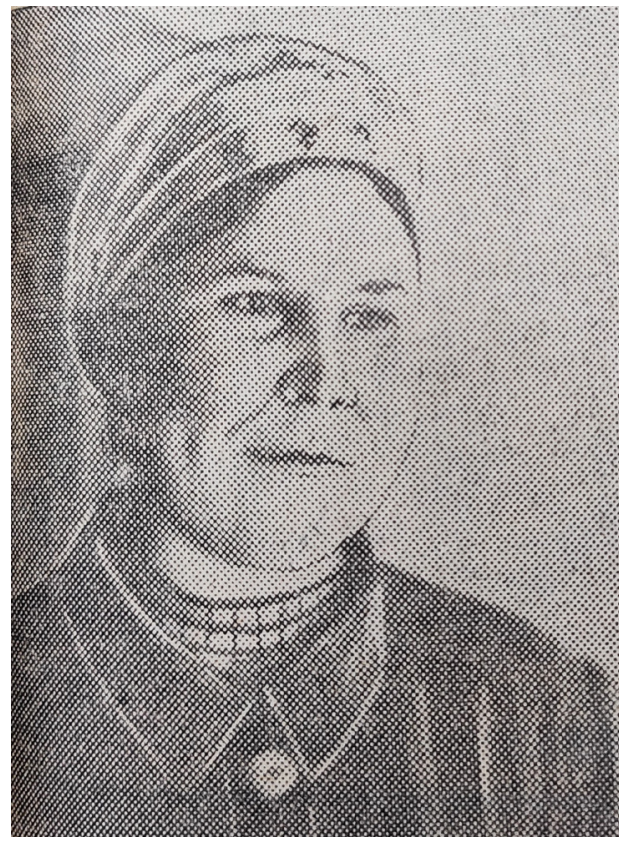

Рис. 6. Доярка Фефелова. Фотография из газеть «Тувинская правда» 1956 г., 8 апреля, № 72. Fig. 6. Fefelova, a dairy maid. Photo from Tuvinskaya Pravda, 1956, No.72, April 8.

службу, там он знакомится с молодой женщиной, прожившей в тайге 14 лет $^{1}$ и т. д. Из другой статьи с красноречивым названием «Нахлебники» выясняется, что жители поселка Шурмак, не включены в общественное производство, а живут исключительно единоличным трудом - охотой и таежными промыслами ${ }^{2}$.

Встречаются в очерках любопытные бытовые детали описания одежды, в которой ходят старообрядческие женщины, звучат фрагменты разговорной речи, наконец, называются имена собеседников. Авторы, сами удивляясь положению дел, вынуждены как-то объяснять этот феномен. И снова на помощь приходит мотив отделенности, - географической и символической, - старообрядческого мира от советской жизни: «Вы здесь не услышите задорных современных песен и звонких детских голосов. Все здесь как будто спит тихим, спокойным сном»³. Религиозным предрассудкам, оттесненным из публичного в приватное пространство, за глухие семейные заборы, удается сохранять свои позиции. Поэтому в старообрядческих семьях, по мнению авторов, и разыгрываются настоящие трагедии, как в молодой семье из Салдама. Очерк «Трагедия в домике на берегу» рассказывает историю комсомолки Тани Килиной, которая погибла от руки мужа-изувера Афанасия Юркова 4 . Показательно, что акцент в статье постоянно смещается с фигуры убийцы на его религиозного брата Иллариона, якобы причастного к делу и превращающегося едва ли не в главного виновника преступления.

Своей задачей авторы текстов, написанных от первого лица, видят не только в разоблачении неприглядных сторон жизни, но, прежде всего, в вовлечении их в другую, альтернативную реальность, где веру в бога заменяет уверенность в будущем, и где они пойдут в общем строю «трудиться на благо народа». В этом смысле символично завершение очерка А. Емельянова «Вкус жизни», героиня которого - многодетная мать из Эржея, - страдающая от побоев мужа-старообрядца и наконец решившаяся уехать из дома в другой поселок. Он встречает ее идущую по широкой и прямой улице Сарыг-Сепа. Ничем не выделяется она среди других прохожих, обыкновенная женщина-работница ${ }^{5}$ (puc. 6).

\section{«Сизим, открой дверь»}

Вышеописанная А. Емельяновым сцена служит, на мой взгляд, своеобразным символом последующих десятилетий, когда, как мы уже наблюдали раньше (1940 - начало 1950-х гг.), старообрядцы вновь растворяются среди массы советских тружеников, утратив свою, пусть и однозначно негативно представленную в прессе, религиозную идентичность. В публикациях периода «развитого социализма» они вновь невидимы, неразличимы в общем строю. И хотя на идеологическом фронте продолжается борьба, в которую вовлекаются общественные науки, издаются многочисленные постановления, призванные усилить атеистическую деятельность, старообрядцы, как религиозное сообщество, на страницах «Тувинской правды» почти не присутствуют.

Их возвращение начинается в конце 1980-х вместе с процессами либерализации общественной жизни. Так, в октябре 1988 г. в газете появляется статья «Сизим, открой дверь» ${ }^{6}$. И хотя ее название, вызывающее ассоциацию с фразой из восточной сказки, стереотипно обыгрывает образ старообрядческой культуры, - таинственной и замкнутой, - это, пожалуй, первая газетная статья о

${ }^{1}$ Благинин Ф. Человек из мглы // Тувинская правда. 1962, 23 сентября, № 226.

${ }^{2}$ Козлова С. Нахлебники // Тувинская правда. 1960, 8 октября, № 201.

${ }^{3}$ Онищенко И. Деяния куранского наставника // Тувинская правда. 1962, 17 февраля, № 41.

${ }^{4}$ Сермавкин Т. Трагедия в домике на берегу // Тувинская правда. 1962, 2 сентября, № 208.

${ }^{5}$ Емельянов А. Вкус жизни // Тувинская правда. 1970, 3 июля, № 154.

${ }^{6}$ Анилекно В. Сизим, открой дверь! // Тувинская правда. 1988, 2 октября, № 228. 
старообрядцах, в которой отсутствует однозначная негативная оценка. Речь в ней идет о переписи населения, для проведения которой участникам экспедиции пришлось преодолеть немало трудностей. Проблемой стали не только путь по глухой тайге, где на шесть тысяч квадратных километров всего семь поселений, но и непредусмотренное инструктажем нежелание некоторых жителей Ужепа отвечать на вопросы анкеты, ссылаясь на свое вероисповедание:

«Скиты староверов не случайно осели в столь обособленных местах - подальше от “глазу мирского”. Вот и теперь, утверждают они, греховно якобы общение с людьми сторонними. Но все же добрая и учтивая беседа со старожилами положительно сказалась на результатах опроса».

Этой работой, знаменующей некую условную границу в способах внешней репрезентации старообрядцев, от атеистической до нейтральной и наконец вполне толерантной, мне бы хотелось завершить свой анализ.

\section{Заключение}

Таким образом на примере публикаций в одном из регулярных периодических изданий был рассмотрен вариант внешней репрезентации старообрядцев Тувы в советское время. Несмотря на однозначную атеистическую направленность рассмотренного исторического отрезка присутствие религиозного сообщества в публичном дискурсе не отличалось равномерностью, что обусловливалось, прежде всего, социальным контекстом, определявшим вектор советской атеистической пропаганды в целом, а также особенностями самой группы, занимавшей специфическое место в религиозном многообразии страны.

Культурные особенности группы, преломленные в прессе сквозь идеологическую линзу, наделяют образы старообрядцев спектром преимущественно негативных характеристик и определяют периферийное и маргинальное местоположение сообщества в социуме. Эти характеристики варьируются, - хотя и в границах жесткой атеистической рамки, - в зависимости от исторического момента. В первые годы советской власти старообрядцы предстают, прежде всего, ее политическими противниками, когда их религиозная принадлежность усиливает социально-классовую чуждость группы. Впоследствии это противостояние смещается в область идеологического соперничества, когда образ старообрядцев конструируется в оппозициях суеверного/ научного, отсталого/ передового, единоличного/ коллективного. В определенные периоды старообрядцы вовсе теряют черты религиозного сообщества, растворяясь в массе советских тружеников и оказываются представленным на страницах газет лишь как участники социалистического строительства.

В прессе представлена лишь внешняя репрезентация сообщества и сами старообрядцы являются объектом интерпретации, лишенным активной возможности рассказать о себе, но все же обнаруживающим свои реакции через речь своих оппонентов. И несмотря на искажающую факты идеологическую основу советских текстов они обладают и определенной информационной ценностью, позволяющей рассматривать их как многослойный источник для исследования тувинского старообрядчества.

\section{СПИСОК ЛИТЕРАТУРЫ}

Боченков, В. В. (2019) Старообрядчество советской эпохи. Епископы Русской Православной старообрядческой церкви, советский период (1918-1991) гг.) : библиографический словарь. М. : Вече. 319 с.

Быкова, Е. В., Костров, А. В. (2019) Старообрядческий лубок «Две дороги - два пути»: комментированное прочтение визуального образа. Киров : ООО «Кировская областная типография». 192 с.

Маадыр, М. С., Седип-оол, М. М. (2020) Газетный фонд Национального архива Республики Тыва // Новые исследования Тувы. № 2. С. 87-102. DOI: https://doi.org/10.25178/nit.2020.2.6

Покровский, Н. Н. (1991) За страницами «Архипелага Гулаг» // Новый мир. № 9. С. 77-90.

Покровский, Н. Н. (1992) Скитские биографии // Новый мир. № 8. С. 194-210.

Покровский, Н. Н., Зольникова, Н. Д. (2002) Староверы-часовенные на востоке России в XVIII-XX вв. : Проблемы творчества и общественного сознания. М. : Памятники общественной мысли. 471 с.

\footnotetext{
${ }^{1}$ Аниленко В. Сизим, открой дверь! // Тувинская правда. 1988, 2 октября, № 228.
} 
Стороженко, А. А. (2019) Старообрядческие монастыри «енисейского меридиана» в XX веке: истоки, традиции и современное состояние // Новые исследования Тувы. № 1. С. 4-15. DOI: https://doi.org/10.25178/nit.2019.1.1

Танова, Е. Д. (1979) Периодическая печать Тувы (1924-1944 гг.). Кызыл : Тувинское книжное издательство. 112 с.

Татаринцева, М. П. (2006) Старообрядцы в Туве: историко-этнографическое исследование. Новосибирск : Наука. 213 с.

Смолкин, В. (2021) Свято место пусто не бывает: история советского атеизма. М. : Новое литературное обозрение. 552 с.

Филатов, С. Б. (1997) Государственно-церковные отношения в России перед демократическим вызовом // Религия и государство в современной России. Научные доклады. Вып. 18. М. : Московский центр Карнеги. 119 с. С. $67-84$.

Дата поступления: 03.05.2021 2.

\section{REFERENCES}

Bochenkov, V. V. (2019) Staroobriadchestvo sovetskoi epokhi. Episkopy Russkoi Pravoslavnoi staroobriadcheskoi tserkvi, sovetskii period (1918-1991) gg.) [Old Believers of the Soviet era. Bishops of the Russian Orthodox Old Believer Church, the Soviet period (1918-1991)]: a bibliographic dictionary. Moscow, Veche. 319 p. (In Russ.).

Bykova, E. V. and Kostrov, A. V. (2019) Staroobriadcheskii lubok «Dve dorogi - dva puti»: kommentirovannoe prochtenie vizual'nogo obraza [Old Believers lubok “Two roads - two ways": an annotated reading of the visual image]. Kirov, OOO «Kirovskaia oblastnaia tipografiia». 192 p. (In Russ.).

Maadyr, M. S. and Sedip-ool, M. M.(2020) Gazetnyi fond Natsional'nogo arkhiva Respubliki Tyva [Newspaper collections at the National Archives of the Republic of Tuva]. New Research of Tuva, no. 2, pp. 87-102. (In Russ.). DOI: https://doi. org/10.25178/nit.2020.2.6

Pokrovskii, N. N. (1991) Za stranitsami «Arkhipelaga Gulag» [Beyond the pages of the Gulag Archipelago]. Novyi mir, no. 9, pp. 77-90. (In Russ.).

Pokrovskii, N. N. (1992) Skitskie biografii [Biographies of skete dwellers]. Novyi mir, no. 8, pp. 194-210. (In Russ.).

Pokrovskii, N. N. and Zol'nikova, N. D. (2002) Starovery-chasovennye na vostoke Rossii v XVIII-XX vv. : Problemy tvorchestva i obshchestvennogo soznaniia [Old believers of the Chasovennoye accord in the East of Russia in the 18th - 20th centuries: Problems of creativity and public consciousness]. Moscow, Pamiatniki istoricheskoi mysli. 471 p. (In Russ.).

Storozhenko, A. A. (2019) Staroobriadcheskie monastyri «eniseiskogo meridiana»v XX veke: istoki, traditsii i sovremennoe sostoianie [Old Belief monasteries of the «Yenisei meridian» in the 20th century: origins, traditions and current state]. New Research of Tuva, no. 1, pp. 4-15. (In Russ.). DOI: https://doi.org/10.25178/nit.2019.1.1

Tanova E. T. (1979) Periodicheskaia pechat' Tuvy (1921-1944 gg.) [Periodical press in Tuva, 1921-1944]. Kyzyl, Tuvan book publ. 112 p. (In Russ.).

Tatarintseva, M. P. (2006) Staroobriadtsy v Tuve: istoriko-etnograficheskii ocherk [Old believers in Tuva: a historical and ethnographic essay]. Novosibirsk, Nauka. 216 p. (In Russ.).

Smolkin, V. (2021) Sviato mesto pusto ne byvaet: istoriia sovetskogo ateizma [A holy place is never empty: the history of Soviet Atheism]. Moscow, Novoe literaturnoe obozrenie. 552 p. (In Russ.).

Filatov, S. B. (1997) Gosudarstvenno-tserkovnye otnosheniia v Rossii pered demokraticheskim vyzovom [State-church relations in Russia: facing the democratic challenge]. In: Religiia i gosudarstvo $v$ sovremennoi Rossii [Religion and the state in modern Russia]. Scientific reports. Vol. 18. Moscow, Moskovskii tsentr Karnegi. 119 p. Pp. 67-84. (In Russ.).

Submission date: 03.05.2021. 